Jelena Osmanovic Zajic ${ }^{1}$

Faculty of Philosophy, University of Nis, Serbia

Jelena Maksimovic ${ }^{2}$

Faculty of Philosophy, University of Nis, Serbia
Original scientific paper

UDC: 371.013

DOI: $10.5937 /$ IstrPed2002354O

\title{
CONTEMPORARY TEACHERS' ACTION RESEARCH - BASIS FOR THE DEVELOPMENT OF REFLECTIVE PRACTICE IN EDUCATION
}

\begin{abstract}
A reflective practitioner is an active individual who explores the possibilities of solving problems in practice and who is characterised by being reflectively open to reexamining their own opinion. The authors of this paper start from the premise that the process of education, however consistent and well-founded it may be, is exposed to constant inspection and improvement. The aim of this research is to identify the teachers' skills needed for conducting action researches. This goal is accomplished by examining the possibility of connecting action researches with teachers' reflective practice. The methods used are the descriptive method, scaling technique and the Likert-type scale (AIRP). This scale examines the teachers' skills for conducting action researches and is based on five factors extracted by the factor analysis: diagnostic skills, attitudes towards action researches, data collecting skills, practical skills and skills needed for conducting action researches. This study involved 305 respondents from the territory of the Republic of Serbia. The obtained results show statistically significant differences between the teachers with long teaching experience and those with a few years of teaching experience, $p<0.05$.

This research represents an attempt to change the current practice at the micro level with the purpose of initiating qualitative changes and improving teaching practice by means of action researches. Therefore, it will be possible to induce changes at the meso and macro level of the system of education.
\end{abstract}

Key words: action researches, reflective practice, education, teachers, research practice.

\section{INTRODUCTION}

Education has always represented a factor essential for the progress of any society. Consequently, it is necessary that teachers who are reflective practitioners should improve their own accomplishments in education in order to reach high standards in their teaching profession. This evidently means that education of teachers has become an issue relevant for the improvement of teaching practice.

Rapid changes, permeating all segments of society, especially education and science, have had an impact on traditional teaching. Namely, the role of the teacher is to be understood as the role of a professional who organizes and assesses their students' achievements by

\footnotetext{
${ }^{1}$ jelena.osmanovic.zajic@filfak.ni.ac.rs

²jelena.maksimovic@filfak.ni.ac.rs
} 
transferring practically applicable knowledge. Therefore, modern school is the school focused on students and learning, on both active and interactive education. When the teacher is provided with feedback information on the classroom climate, then the teacher is able to reflect on and discuss the obtained information. The process of searching for new knowledge with the purpose of altering the present situation is based on action researches. This process can be referred to as learning by changing and changing by learning (Bognar \& MompointGaillard, 2017; Bognar \& Krumes, 2017).

Reflection is the cornerstone of every research cycle, and the ability to think often refers to quality teaching. Although many teachers think about everyday events, activities and achievements in the classroom, research activities, planning and reflection can affect not only the change of teachers, but the whole educational context. By conducting action research, reflexive practice focuses on an individual in the professional domain and on self-awareness, which is again important as a prerequisite for professional development. Therefore, it can be considered that the best way to implement reflexive practice in the educational process is to support action research. The subject of this research was the attitudes of teachers that actually represent a reflection of self-assessment of the teachers' competence to conduct action research. The research used the descriptive method, a scaling technique with the Likert-type scale instrument. A total of 305 respondents were included on the territory of the Republic of Serbia. Factor analysis with Varimax rotation has retained the 5 main factors on the basis of which further statistical analysis was carried out: identification of problems (important for carrying out action research), general attitude (positive - negative) towards action research, research skills in data collection (self-assessment of teachers' competence for research work), practical activities of teachers, skills and abilities of teachers for conducting action research. The survey found that regardless of whether general class teachers or subject teachers are in question, attitudes and competences for planning and the implementation of action research do not depend on the professional qualifications of teachers. The hypothesis about the existence of a statistically significant difference in relation to the professional qualification variable was rejected. The research showed that work experience has its share in this segment, that is, it plays a role in the development of reflexivity of teaching practice, and the results showed that there is a statistically significant difference in respondents' responses compared to the years of service variable, which confirmed the second hypothesis.

Action research and reflexive practice simply enable teachers to start from individual experience and perspectives, to develop awareness of the evaluation of time and every effort spent on reflection, which again enables the planning of the following steps for teachers: acquisition of pedagogical and research knowledge and skills, understanding of the self, potentials for improving professional practice, initiating and maintaining changes in the educational process.

\section{THE ROLE OF ACTION RESEARCHES AND REFLECTIVE PRACTICE IN EDUCATION}

The fact that differentiates action researches from other types of pedagogical researches is their adaptable and flexible organization. The action research project is detailed, open and creative, which means that it may be continually changed, corrected and upgraded throughout the research process. The action research does not recognize a division between researchers and respondents but only the participants in teaching process, i.e. practitioners and their researchers, where practitioners are potential researchers and researchers are practitioners. Researchers are involved in exploring their own practice in cooperation with 
other participants, who in turn become potential researchers (McNiff \& Whitehead, 2002). This type of teaching practice research is characteristic of teachers who are reflective practitioners.

Present-day action researches are remarkable in that problems are identified and solved by practitioners themselves, not professional researchers (Bognar, 2008; Bognar \& MompointGaillard, 2017; Bognar \& Krumes, 2017; Simel \& Bognar, 2017), while all the participants in the research activities are considered researchers, comprising a research team that conducts the research in question. All of them are involved in the estimation of certain research stages, giving suggestions for a further course of development and deciding about and assessing the research as a whole. Carr and Kemmis (Carr \& Kemmis, 1986) state that the goal of action researches is the improvement of teaching practice and education in three areas: improvement of practice, improvement of practice understanding by teachers themselves and improvement of the climate in which practice is done. Therefore, action researchers are regarded as a straightforward, natural and possibly the most adequate way of a simultaneous transformation and improvement of teaching practice because of the fact that their fundamental characteristic is a dedication to solving particular and specific problems that practitioners encounter.

Reflective practice is discussed by numerous authors (Bognar \& Mompoint-Gaillard, 2017; Bognar \& Krumes, 2017; Carr, 2005; Colton \& Sparks-Langer, 1993; Dewey, 1933; Grimmetti et al., 1990; Gorli et al., 2015; Hibbert et al., 2014; Johnston \& Badley, 1996; Jay \& Johnson, 2002). The teacher must be a practitioner and practice theorist oriented towards lifelong learning. Their work helps in defining the teacher who is a reflective practitioner. The teacher who is a reflective practitioner is an active individual, willing to reexamine their own opinions and explore various possibilities and procedures in order to solve practical problems encountered in everyday practice. Thus, this is the person who is actively involved in teaching practice, who carefully observes all activities and who consequently searches for the methods and techniques to develop them properly.

The reason why teachers are often not acquainted with the term reflective teaching lies in the fact that reflection itself is not clearly defined (Rodgers, 2002, p. 843): (1) How does it differ from other approaches? (2) Which skills reveal reflection? (3) How can teachers talk about reflection without common understanding? (4) How to explore teachers' and students' advancement without knowing clearly what reflection means?

The connection between action researches and reflective practice is proved by the fact that reflection practitioners are oriented towards lifelong learning and improvement. Their education is never completed since they are dedicated to solving problems encountered in everyday practice and to improving their own practical work.

Action researches are primarily initiated by the needs and abilities of teachers who are action researchers, not by the ideas of individuals or institutions operating outside the context of education (Bognar \& Krumes, 2017; Bognar \& Mompoint-Gaillard, 2017; Bognar, 2008; Simel \& Bognar, 2017). Therefore, they are most closely related to the contemporary meaning of practice. Action researches contribute to teachers' improving their own skills for becoming reflective teachers and researchers by simultaneously assisting them in modelling basic research activities for their students. Although action research can have a significant impact on teachers' reflective practice, their own research and system of beliefs, not all of these programmes have been equally successful. Teachers have to be offered opportunity to form 
their opinions through their own research, not only through other people's experience. The programmes that merely enable potential teachers-researchers to experience only the stages of planning the project and not those of carrying it out do not contribute to teachers being better reflection practitioners (Christenson et al., 2002; Lustick, 2009). These studies prove that teachers' experience in exploring activities in continuity greatly influence teachers' ability to reflect on their own teaching practice and pose appropriate questions that help in resolving challenges they encounter in their classrooms. "It can be stated that reflective practice is a cyclical process of experiential learning through action research. With the research attitude towards practice, the teacher critically re-examines his/her actions, directs himself/herself towards reflective practice and is professionally promoted and improved" (Dedaj, 2016, p. 44). Teaching profession is unique in itself, each teacher has their own unique experience that they interpret in their own manner, depending on time and context (Lomax, 1996). Each teacher differently comprehends the ideas of professionalism and reflection. Thinking about reflection practice thus yields evident consequences: teachers describe, analyze and plan the ways of improving their practice in their own manner. This is authentic teachers' reflection that requires an authentic reply and that facilitates planning of improvement, based on the strategies that enable an individual approach to changes, necessary for the improvement of professional practice (Sellars, 2014).

„Teachers are therefore enabled to start from their own individual experience and perspective, to value time and effort spent on reflection, which all contributes to planning further steps to be undertaken by teachers" (Sellars, 2012, p. 467): pedagogical and content knowledge, understanding your own self and your own potentials needed for the improvement of professional practice, initiation and retention of changes.

A reflection practitioner may be puzzled by the question of improving and developing additional competences, but what defines an efficient reflective practitioner is a set of attitudes towards practice based on a thorough understanding of one's own self, society and goals to be accomplished.

Bogdan and Biklen (1982) noticed a long time ago that those teachers who were not employed in the academic sector conducted researches for practical purposes, defined research as a kind of applied research in which a reasearcher was actively included to accomplish the goals set by the subject of the research. These authors suggested that the goals of this kind of reasearches involved action, training and decision making, which made them different from scientific and scholarly researches.

Contemporary teaching requires competent teachers who organize their work, encourage and motivate their students since teachers' competences influence the standards for their students' achievements. This means that modern teachers should design their classes and become researchers, advisors, programmers, pedagogical diagnosticians, therapists and educators of generations of young people (Noffke \& Somekh, 2009).

Vaughan and Burnaford (2015) made a list of resource materials for the period from 2000 to 2015, related to teachers' education, with a particular emphasis on the significance and goals of the activities conducted within the programmes for teachers' education. These activities are to be taken into account during teachers' bachelor studies. Therefore, teachers have to develop, examine, reexamine and survey their knowledge and their abilities to use that knowledge with the purpose of improving their professional practice, the practical application of their knowledge (Burnaford, 2011). 
The analysis of resource materials proves that the goals of action researches are identical to the goals of reflective practice: transformation and improvement of teaching (Atkin, 1993; Bognar \& Mompoint-Gaillard, 2017; Bognar \& Krumes, 2017; Carr \& Kemmis, 1986; Coghlan \& Brydon-Miller, 2014; Cochran-Smith \& Lytle, 2009; Done, 2014; Elliott, 1991; Farren et al., 2011; Whitehead, 1989).

Numerous experts in the field (Bognar, 2011; Bognar \& Mompoint-Gaillard, 2017; Bognar \& Krumes, 2017; Farrell, 2004; LaBoskey, 1994; Rahmi et al., 2016; Schon, 1987; Zeichner \& Liston, 1996; Zeichner \& Noffke, 2001) conducted theoretical and empirical studies concerned with the contribution of reflective practice to teachers' efficiency. The results of these studies demonstrate that reflective practice prevents teachers from reacting impulsively and routinely, that it helps them in creating everyday experiences, that it enables them to act purposefully and intentionally, that it elevates their level of consciousness considering teaching, that it provides better understanding and creates positive changes. "Reflexivity is a developmental process of experiential learning. The essence is to use experiences from practice and to approach it critically in order to improve it. The skills on which the concept of reflective practice is based are: thinking about one's practice, connecting theory and practice, and critical analysis and evaluation of actions" (Dedaj, 2019, p. 19). Here is an example of the connection between action research and reflective practice. If the teacher carried out an action, if the lesson was successful, one can think about the reasons that contributed to that. If students showed poor motivation to learn or, for example, disrupted the class, it is necessary to re-examine why they did it, in which parts of the class it was most dominant and the like. The teacher finds solutions and starts with some activity that will change the situation in the class.

In summary, the basic feature of action research is their focus on solving specific problems that practicing teachers encounter in educational practice. The fact is that all pedagogical research aims to improve educational practice. Therefore, it was very important to examine the perceptions of teachers of reflective practitioners about this specific type of research and to assess whether they feel empowered enough to conduct them.The research presented in this paper examined the attitudes of teachers, which are actually the reflection of teachers' self-assessment of their competence in conducting action researches. Teachers' selfassessments were analyzed in five domains: action research skills in diagnosing problems of education, attitudes towards action researches, skills of data collecting, a practical skill of encountering problems of learning, skills needed for conducting action researches.

\section{METHODS}

The goal of action researches is the improvement of education and teaching; however, their distinctive characteristic is that problems are identified and solved by teachers themselves, not professional researchers. These researches enable solving specific problems that teachers encounter in their practice, which means that they contribute to practice improvement. It is of utter importance to examine teachers' perspective on this problem, which is also the subject of this research.

This research particularly emphasizes the independent variables: professional training of teachers and their teaching experience, which were used to explore the differences between the respondents considering their skills for conducting action researches. The analysis of the variances of the overall results and of the results regarding the skills for conducting action researches was based on the independent variables - professional training of teachers, which 
included two categories (class teachers and subject teachers), and teaching experience (1-10 years of experience; 11-20 years of experience in teaching; 21-30 years of teaching experience). The postulated specific hypotheses were related to the assumptions that planning and realizing of action researches, as well as skills and competences of teachers for conducting action researches in teaching practice, varied in relation to the set research variables, i.e. that there would be statistically significant differences between the responses provided by class teachers and those given by subject teachers, and between the responses of teachers with short and those with long teaching experience. The research sample was selected by random sampling. Previous knowledge on action research, professional training in this field and the like were not taken into account, but only data on work experience and the education cycle were taken into account. The aim of the research was aimed at discovering the real crosssection of knowledge and application of action research with the aim of implying further affirmation of action research and providing a basis for further empirical and comparative research in this domain.

The methods applied in the research were the descriptive method, the scaling technique and the Likert-type scale (AIRP). The empirical research took into consideration all the metric characteristics of the instrument. The variable consistency for the selected sample was inspected, and the instrument validity and reliability were tested by the Kronbah Alpha test. The Kronbach Alpha test was 0.85 (the value $>0.70$ is recommended for the acceptance of the instrument), while the Bartlett's test of the statistical significance proved to be statistically significant $(p=0.00)$, which showed that the instrument was consistent and reliable for the research requirements. This data indicates that the assessment scale has metric characteristics and that there is an internal consistency of the items for the sample of respondents included in this study.

The research included 305 respondents from the territory of the Republic of Serbia. The sample of the research was a random stratified sample based on the probability theory that involved primary school teachers from various districts of Serbia (the City of Belgrade, Vojvodina, Jablanica District, Pčinja District, Pirot District, Toplica District, Šumadija District, Pomoravlje District, Zlatibor District).

\section{RESULTS AND INTERPRETATION OF THE RESULTS OF THE RESEARCH}

The Likert-type scale contained 33 items. The Kaiser-Meyer-Oklin and Bartlett's tests were used to determine whether the factor analysis was adequate to be used for the statistical analysis.

Table 1: KMO and Bartlett's test of the statistical significance Kaiser-Meyer-Olkin Measure of Sampling Adequacy. 0,780

Bartlett's Test of Sphericity

Approx. Chi-Square

4598.277

df

Sig. 0,000

If the value of the KMO test is higher than 0.60 , and if the value of the Bartlett's test is lower than 0.05 , i.e. statistically significant, then the factor analysis is an adequate statistical procedure. Table 1 shows that the KMO test is 0.78 while the Bartlett's test has a statistically significant value of $p=0.00$, which justifies the adequacy of the data needed for the factor analysis. 
Table 2: Factor analysis of the data Components

Initial values

Extracted values

\begin{tabular}{lrrrrrr}
\hline & Total & \% of variance & Cumulative \% & Total & \% of variance & Cumulative \% \\
\hline 1 & & & & & & \\
2 & 6.926 & 20.987 & 20.987 & 6.926 & 20.987 & 20.987 \\
3 & 4.648 & 14.084 & 35.071 & 4.648 & 14.084 & 35.071 \\
4 & 2.159 & 6.541 & 41.613 & 2.159 & 6.541 & 41.613 \\
5 & 1.693 & 5.129 & 46.742 & 1.693 & 5.129 & 46.742 \\
6 & 1.568 & 4.751 & 51.493 & 1.568 & 4.751 & 51.493 \\
7 & 1.514 & 4.587 & 56.081 & 1.514 & 4.587 & 56.081 \\
8 & 1.332 & 4.036 & 60.116 & 1.332 & 4.036 & 60.116 \\
\hline
\end{tabular}

Extraction Method: Principal Component Analysis.

Table 2 presents extracted factors. The number of factors to be extracted had to be determined by the Keizer criterion, which took into account only those factors whose characteristic values were 1 or higher. These values were determined in 8 factors (6.926; $4.648 ; 2.159 ; 1.693 ; 1.568 ; 1.514 ; 1.071 ; 1.332)$.

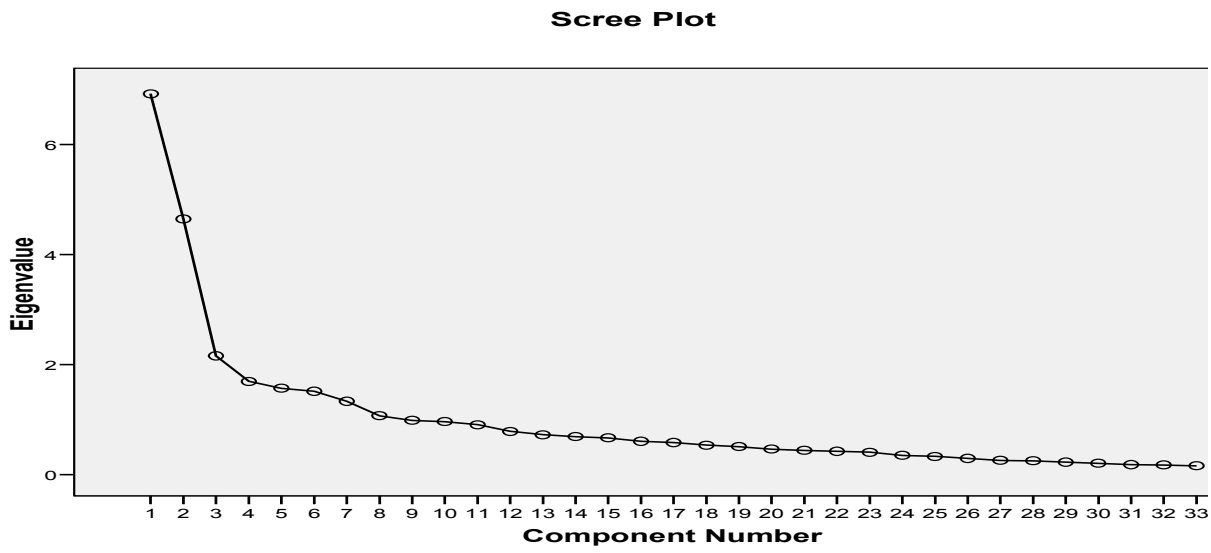

Graph 1: Scree Plot diagram

Graph 1 also shows that the factor analysis was used to extract 8 factors by means of the Varimax rotation. The elbow of the graph might be determined at the eighth factor, yet, due to a great number of factors, it was established at the fifth factor, which comprised over $50 \%$ of the total cumulative variance. The matrix of the factors structure was obtained by means of the factor rotation.

In the study of teachers' skills, the research items were grouped into the extracted factors, 
which were named as follows: 1. recognition of problems (important for the realization of action researches), 2. general attitude (positive or negative) towards action research, 3 . research skills necessary for data collecting (teachers' self-assessment regarding their competence for conducting researches), 4. teachers' practical activities, 5. teachers' skillfullness and readiness to conduct action researches.

The most frequently used parametric test for testing the significance of the differences between two arithmetic means is the $t$ test. It was used in this research in order to explore the differences in attitudes between class teachers and subject teachers.

The research yielded certain important results. The results are presented on the basis of data factorization, where the respondents' self-reflection on action research and reflective practice was primarily singled out.

Table 3: Teachers' competences and attitudes towards conducting action researches considering their professional training

\begin{tabular}{|c|c|c|c|c|}
\hline & & $M$ & $\mathrm{t}$ & $\mathrm{p}$ \\
\hline Recognition of relevant problems & $\begin{array}{l}\text { Class teachers } \\
\text { Subject teachers }\end{array}$ & $\begin{array}{l}40.31 \\
40.92\end{array}$ & 0.17 & 0.51 \\
\hline Attitude towards action researches & $\begin{array}{c}\text { Class teachers } \\
\text { Subject teachers }\end{array}$ & $\begin{array}{l}32.10 \\
33.00\end{array}$ & 0.15 & 0.40 \\
\hline Data collecting skill & $\begin{array}{c}\text { Class teachers } \\
\text { Subject teachers }\end{array}$ & $\begin{array}{l}20.02 \\
20.15\end{array}$ & 0.60 & 0.70 \\
\hline Practical activities & $\begin{array}{c}\text { Class teachers } \\
\text { Subject teachers }\end{array}$ & $\begin{array}{l}25.42 \\
25.62\end{array}$ & 0.45 & 0.90 \\
\hline $\begin{array}{l}\text { Skills for conducting action } \\
\text { researches }\end{array}$ & $\begin{array}{c}\text { Class teachers } \\
\text { Subject teachers }\end{array}$ & $\begin{array}{l}40.31 \\
40.92\end{array}$ & 0.63 & 0.60 \\
\hline
\end{tabular}

The research demonstrated that the respondents' replies were homogenous. Therefore, it is concluded that teachers' competences and attitudes towards planning and realizing action researches, regardless of them being either class teachers or subject teachers, do not depend on teachers' professional training ( $p>0,05)$. The obtained result disproved the first specific hypothesis: there is a statistically significant difference between respondents' responses considering the variable professional training.

On the other hand, the most frequently used parametric test for testing the significance of the differences between three or more arithmetic means is the ANOVA test, or the Fisher's test (F). It was used in this research in order to examine the differences in attitudes of teachers regarding their teaching experience.

Table 4: Teachers' competences and attitudes towards conducting action researches considering their teaching experience

\begin{tabular}{ccccc} 
& & $\mathrm{M}$ & $\mathrm{F}$ & \\
\hline & & & & \\
Recognition of relevant problems & 1-10 years & 34.71 & 0.90 & 0.40 \\
& $11-20$ years & 34.71 & & \\
\hline Attitude towards action researches & $21-30$ years & 35.75 & & \\
& $1-10$ years & 33.56 & 2.78 & $\mathbf{0 . 0 2}$ \\
& $11-20$ years & 32.64 & & \\
\hline
\end{tabular}




\begin{tabular}{|c|c|c|c|c|}
\hline \multirow[t]{3}{*}{ Data collecting skill } & $1-10$ years & 24.61 & 3.40 & 0.03 \\
\hline & $11-20$ years & 23.43 & & \\
\hline & 21-30 years & 28.85 & & \\
\hline \multirow[t]{3}{*}{ Practical activities } & $1-10$ years & 20.31 & 4.74 & 001 \\
\hline & $11-20$ years & 21.33 & & \\
\hline & 21-30 years & 28.35 & & \\
\hline \multirow[t]{3}{*}{ Skills for conducting action researches } & 1-10 years & 30.25 & 4.15 & 0.03 \\
\hline & $11-20$ years & 31.30 & & \\
\hline & 21-30 years & 38.45 & & \\
\hline
\end{tabular}

Unlike the homogenous results shown in Table 3 obtained from the responses of both class teachers and subject teachers, Table 4 shows completely different results. The extraction of the highest arithmetic mean regarding the factor "Attitude towards action researches" proves that the responses of the teachers with the longest teaching experience were significantly different from those given by their younger colleagues in their positive assessment $(p<0,05$; $p=0,02)$.

The differences are evident regarding the factor "Data collecting skill". The teachers with longer teaching experience showed better results than their younger colleagues. The difference in arithmetic means is statistically significant $(p<0,05 ; p=0,03)$.

Moreover, the teachers with long teaching experience had better results than their younger colleagues regarding the factor "Practical activities". Practical activities, essential for conducting action researches, proved as prevalent among the teachers with long teaching experience. This difference was statistically significant $(p<0,05 ; p=0,01)$.

Finally, a statistically significant difference in the respondents' responses was detected regarding the factor "Skills for conducting action researches". Teaching experience again proved to be of great significance. The responses provided by the teachers with the longest teaching experience differed from those given by their younger colleagues, the difference being statistically significant $(p<0,05 ; p=0,03)$.

The obtained results confirmed the second specific hypothesis: there is a statistically significant difference between the respondents' responses considering the variable teaching experience.

The correlation analysis was one more statistical indicator that yielded significant results. Correlation represents the state of mutuality and reciprocity. Correlation is also the pattern of the variation of variables depending on the manner in which they are connected. The Pearson Correlation was applied in this research.

Table 5: Correlation between conducting action researches and teachers' professional training and their teaching experience

\begin{tabular}{ccccc} 
& & $\begin{array}{c}\text { Professional } \\
\text { training }\end{array}$ & $\begin{array}{c}\text { Teaching } \\
\text { experience }\end{array}$ & $\begin{array}{c}\text { Action } \\
\text { researches }\end{array}$ \\
\hline \multirow{2}{*}{ Action } & Pearson Correlation & -0.03 & & 1 \\
researches & Sig. (2-tailed) & 0.76 & 0.16 & \\
& $\mathrm{~N}$ & 200 & 0.05 & 200 \\
\hline
\end{tabular}


Table 5 confirms the aforementioned conclusions. The Pearson Correlation made it possible to connect the subject of the research with the research independent variables. The constructed instrument was arranged into one unique variable Action researches. The obtained results showed that the attitudes towards action researches and the sense of competence for conducting them correlated with the variable teaching experience at the level of statistical significance. The correlation was positive, which proves that the teachers with long teaching experience had more positive attitudes towards action researches than their younger and less experiences colleagues, and that they consequently recognized themselves as reflective practitioners. The correlation is statistically significant $\mathrm{p}=0,05$.

\section{CONCLUSION}

Teachers become reflective practitioners, teachers-researchers or action researchers by undertaking an active role in teaching researches (Brookfield, 1995; Schon, 1983; 1987; 1990). Action research represents the basis for the development of reflective teaching practice. Conducting a particular action research and merely being a teacher - reflective practitioner are different because in the former case, individuals are required to organize all of their thoughts and ideas so as to improve teaching and education and thus attract the attention of all the participants in this process. Action researches have been an efficient strategy of teachers' professional advancement at all levels of education for the past two decades.

Any research is a journey into the unknown because if the subject of the research were known, then there would be no need to study it. Action researches can be applied in practice but it requires a detailed knowledge of the procedures of action researches. The idea of a teacher who is also a researcher is a rather powerful one, likely to resolve all problems related to school and teaching. This idea is an addition and certainly an alternative to systematic attempts aimed at improving education; it is the reflection of the conviction that schools and their teachers can be initiators of the development, as well as that teachers' professional advancement during one school year is of crucial importance.

To sum up, action researches are considered to be an important means of teachers' improvement and comprise six concepts: an immediate identification of problems, planning of interventions, execution of interventions, evaluating results, reflective practice, emancipation, critical theory, professional development, research of practitioners. The goal of action researches is the improvement of education and teaching, but their particular characteristic is the fact that problems are identified and solved by teachers themselves, not professional researchers. Action researches contribute to solving specific problems that teachers encounter in their everyday practice, and they thus contribute to the improvement of practice (Cohen et al., 2011; Somekh, 2005).

The presented research and its results lead to the conclusion that teachers have a positive attitude towards conducting action researches, that they recognize the subject matter and methodology of action researches. It is concluded that teaching experience has a significant impact on the development of reflective teaching.

The teachers with longer teaching experience are more likely to be better reflective practitioners than their less experienced colleagues.

The obtained results confirm the general hypothesis partially since the differences are evident regarding the variable teaching experience, not regarding teachers' professional training. 
Hypothetically speaking, some future researches might give different results. Namely, if the same sample of currently less experienced and young teachers were analyzed in some further studies, they would be then more experienced and consequently more adequate action researchers and reflective practitioners.

That teachers become the initiators of changes is of utter importance. This can be accomplished only on condition that they undertake new professional roles such as critical friends, reflective practitioners and action researchers, which further contributes to the professionalization of teaching. Crucial changes cannot be accomplished in a short period of time, nor with a small number of teachers. The expected long-term changes can be achieved if supported by professional improvement and projects organized by schools.

\section{References}

Atkin, J. M. (1993). Developments in the Philosophy/Sociology of Science and Action Research. Educational Action Research, 1(1) 187-188.

Bogdan, R. C., \& Biklen, K. S. (1982). Qualitative Research for Education: An Introduction to Theory and Methods. Allyn and Bacon, Inc.: Boston London.

Bognar, B., \& Krumes, I. (2017). Encouraging reflection and critical friendship in preservice teacher education. CEPS Journal, 7(3), 87-112.

Bognar, B., \& Mompoint-Gaillard, P. (Eds.). (2017). Creating an online community of action researchers. Strasbourg: Council of Europe Publishing.

Bognar, B. (2011). Problemi u ostvarivanju sustinskih promjena u odgojnoj praksi posredstvom akcijskih istraživanja. U M. Micanović (ur.), Akcijsko istrazivanje i profesionalni razvoj ucitelja i nastavnika (str. 41-60). Zagreb: Agencija za odgoj i obrazovanje.

Bognar, B. (2008). Mogucnost ostvarivanja uloge ucitelja - akcijskog istrazivaca posredstvom elektronickog ucenja. Doktorska disertacija. Zagreb: Filozofski fakultet.

Brookfield, S. (1995). Becoming a Critically Reflective Teacher. San Francisco: Jossey-Bass Publicher.

Burnaford, G. (2011). Experienced Educators and Practitioner Research: The Challenge for University Graduate Programs. In Practitioner Research in Teacher Education: Theory \& Best Practices, edited by I. M. Saleh \& M. S. Khine, pp. 307-324. Emirates College for Advanced Education. United Arab Emirates \& Frankfurt: Peter Lang.

Carr, W. (2005). The role of theory in the professional development of an educational theorist. Pedagogy, Culture \& Society, 13(3), 333-345.

Carr, W., \& Kemmis, S. (1986). Becoming critical: Education, knowledge and action research. London: Deakin University Press.

Christenson, M., Slutsky, R., Bendau, S., Covert, J., Dyer, J., Risko, G., \& Johnston, M. (2002). The Rocky Road of Teachers Becoming Action Researchers. Teaching and Teacher Education, 18(3), 259-272.

Colton, A. B., \& Sparks-Langer, G. M. (1993). A conceptual framework to guide the development of teacher reflection and decision making. Journal of Teacher Education, 44(1) 45-54.

Cohen, L., Manion, L., Morrison, K. (2011). Research Methods in Education. 7th edition. London: Routledge 
Cochran-Smith, M., \& Lytle, S. L. (2009). Inquiry as stance: Practitioner research for the next generation. New York: Teachers College Press.

Coghlan, D. \& Brydon-Miller, M. (2014). The SAGE encyclopedia of action research. Los Angeles, CA: SAGE

Dedaj, M. (2019). Akciona istrazivanja u funkciji refleksivne prakse vaspitaca. Sinteze, 16, 87-94.

Dedaj, M. (2016). Akciona istrazivanja u funkciji profesionalnog razvoja vaspitaca, Pedagoska stvarnost,61(1), 38-46.

Dewey, J. (1933). How we think: A restatement of the relation of reflective thinking to the educative process. Boston; New York: D.C. Heath \& Company

Done, N. B. (2014). On the necessity of intertwining 'knowledge in practice' in action research. International Journal of Action Research, 10(1), 54-97.

Elliott, J. (1991). Action Research for Educational Change. Buckingham: Open University Press.

Farren, M., Whitehead, J., \& Bognar, B. (2011). Action research in the educational workplace. Bethesda; Dublin; Palo Alto: Academica Press.

Farrell, T. S. C. (2004). Reflective Practice in Action: 80 Reflection Breaks for Busy Teachers. Corwin Press (Sage Publications): Thousand Oaks, CA (USA).

Gorli, M., Nicolini, D., \& Scaratti, G. (2015). Reflexivity in practice: tools and conditions for developing organizational authorship. Human Relations, 68(8), 1347-1375.

Grimmetti, P., Mackinnon, A., Erickson, G., \& Riecken, T. (1990). Reflective practice in teacher education. In R. Clift, W. Houston and M. Pugach (Eds.). Encouraging reflective practice in education: an analysis of issues and programs. NY: Teachers College Press.

Hibbert P., Sillince J., Diefenbach, T., Cunliffe, A. (2014). Relationally Reflexive Practice: A Generative Approach to Theory Development in Qualitative Research. Organizational Research Methods, 17(3) 278-298.

Jay, J. K., \& Johnson, K. L. (2002). Capturing complexity: a typology of reflective practice for teacher education. Teaching and Teacher Education, 18(1), 73-85.

Johnston, R., \& Badley, G. (1996). The Competent Reflective Practitioner. Innovation and Learning in Education, 2(1), 4-10.

LaBoskey, V. K. (1994). Development of reflective practice: a study of preservice teachers. New York; London: Teachers College Press.

Lomax, P. (1996). Quality management in education: Sustaining vision through action research. London: Routledge.

Lustick, D. (2009). The Failure of Inquiry: Preparing Science Teachers with an Authentic Investigation. Journal of Science Teacher Education, 20(6), 583-604.

McNiff, J., \& Whitehed, J. (2002). Action research: Principles and practice. London and New York: Routledge/Falmer.

Noffke, S., \& Somekh, B. (2009). Handbook of educational action research. London, England, and Thousand Oaks, CA: Sage.

Rahimi, A., Madani, A. \& Rahimi, H. (2016). University teachers 'action research: An adventure into uncharted waters? International Journal of Learning and Teaching, 8(4), 262-272

Rodgers, C. (2002). Defining Reflection: Another Look at John Dewey and Reflective Thinking, Teachers College Record, 104(4), 842-866.

Sellars, M. (2014). Reflective Practice for Teachers. London: Sage Publications.

Sellars, M. (2012). Teachers and change: The role of reflective practice. Procedia - Social and Behavioral Sciences, 55(2012), 461-469.

Schon, D. (1990). Educating the reflective practitioner: Toward a new design for teaching and learning in the professions. San Francisco: Jossey-Bass.

Schon, D. (1987). Educating the Reflective Practitioner: Toward a design for teaching and learning in the professionals. San Francisco: Jossey-Bass. 
Schon, D. A. (1983). The Reflective Practitioner. New York: Basic Books.

Simel, S., \& Bognar, B. (2017). Positive orientation to education and critical friendship. U B. Bognar, \& P. Mompoint-Gaillard (ur.), Creating an online community of action researchers (pp. 149-170). Strasbourg: Council of Europe Publishing.

Somekh, B. (2005). Action Research: A Methodology for Change and Development. New York: McGraw-Hill Education

Vaughan, M., \& Burnaford, G. (2015). Action research in graduate teacher education: A review of the literature 2000-2015. Educational Action Research, 24(2), 280-299.

Whitehead, J. (1989). Creating a living educational theory from questions of the kind, 'How do I improve my practice?'. Cambridge Journal of Education, 19(1), 41-52

Zeichner, K. M., \& Noffke, S. (2001). Practitioner research. In V. Richardson (Ed.), Handbook of research on teaching (4th ed., pp. 298-330). Washington, D.C.: American Educational Research Association.

Zeichner, K., \& Liston, D. (1996). Reflective Teaching: an introduction. Mahwah, New Jersey: Lawrence Erlbaum Associates.

\section{Biographical notes:}

Jelena Osmanovic Zajic graduated the Faculty of Philosophy in Niš at the Department of Pedagogy in 2012, and then completed her master studies in 2014. Ma Jelena Osmanović is teaching assistant at the Department of Pedagogy at the Faculty of Philosophy of the University of Niš and she is a student of doctoral studies (University of Nis, Faculty of Philosophy). She published more then 50 scientific papers in the field of education, research and pedagogy. Scientific area: Methodology of pedagogical research, Research in pedagogy, Statistics in pedagogy research.

Jelena Ž. Maksimović graduated from the Faculty of Philosophy, Pedagogy Department, University of Priština (Kosovska Mitrovica) in 2001. In the same year, she enrolled in the postgraduate studies at the Pedagogy Department, Faculty of Philosophy in Kosovska Mitrovica. Upon the completion of her master's studies, she defended the master's thesis Various Methodological Approaches to the Research of Academic Failure and was awarded a degree of Master of Pedagogy in 2007. She defended her doctoral dissertation entitled The Role of Action Researches in the Improvement of Teaching Practice. On 2002 she started her teaching career at the Pedagogy Department, Faculty of Philosophy, University of Niš, as a teaching assistant for the academic courses Methodology of Pedagogical Research and Statistics in Pedagogy, and from December, 2007, as an assistant teaching the academic courses Pedagogical Methodology and Statistics in Pedagogy. She was promoted to an assistant professor for the scientific discipline Pedagogy (Pedagogical Methodology and Research in Pedagogy) at the Faculty of Philosophy, University of Niš on 2011. She was elected associate professor for the scientific discipline Pedagogy (Pedagogical Methodology and Research in Pedagogy) on 2016. 